\title{
The choice of surgical treatment method of perforated pyloroduodenal ulcer
}

\author{
D. V. Maksymchuk ${ }^{1}$, V. I. Mamchich ${ }^{1}$, V. D. Maksymchuk ${ }^{2}$
}

${ }^{1}$ Shupyk National University of Health of Ukraine, Kyiv, ${ }^{2}$ Chornobayiv Multidisciplinary Hospital

\section{Вибір способу хірургічного лікування перфоративноі пілородуоденальної виразки}

\author{
Д. В. Максимчук ${ }^{1}$, В. І. Мамчич ${ }^{1}$, В. Д. Максимчук ${ }^{2}$ \\ ${ }^{1}$ Національний університет охорони здоров’я України імені П. Л. Шупика, м. Київ, \\ гЧорнобаївська багатопрофільна лікарня
}

\begin{abstract}
Objective. To develop a method of organ-saving operation aimed at preservation of the physiological function of the pylorus and the normal physiological functioning of the pyloroduodenal area in patients with combined perforated, stenotic pyloroduodenal ulcers.

Materials and methods. The study included 60 patients who faced surgery treatment in relation to complicated combined perforated, stenotic pyloroduodenal ulcers. Depending on diagnostic and surgical tactics applied, patients were conditionally divided into two groups. The control group consisted of 30 patients who underwent standard suturing methods. The main group also consisted of 30 patients in whom the developed method was applicated.

Results. In the control group at the postoperative period of 30 patients operated in different ways complications occurred in 12 persons or in $40 \%$ of cases. In the main group of 30 patients operated according to the proposed method, complication in the form of anastomositis occurred in 1 patient only.

Conclusions. The obtained results substantiate recommendation to clinical application the suggested method of organ-saving operation aimed to preserve the physiological function of the pyloroduodenal area, which excludes perforated ulcers suturing without pyloric stenosis elimination and gastrectomy on the background of peritonitis.

Keywords: peptic ulcer disease; pyloroduodenal ulcer; pylorus stenosis; perforated ulcer; bleeding; penetration; gastrectomy; mo bilization of the duodenum.

Реферат

Мета. Розробити спосіб органозберігаючої операції для збереження фізіологічної функції воротаря та нормального фізіологічного функціонування пілородуоденальної ділянки при поєднаних перфоративних, стенозуючих пілородуоденальних виразках.

Матеріали і методи. У дослідження включено 60 пацієнтів, оперованих з приводу ускладнених поєднаних перфоративних, стенозуючих пілородуоденальних виразок. Хворих у залежності від застосованої діагностичної і хірургічної тактики умовно розподілили на дві групи. Контрольну групу склали 30 пацієнтів, яким були виконані стандартні способи ушивання. Основну групу склали також 30 пацієнтів, у яких було застосовано розроблений спосіб.

Результати. У контрольній групі в післяопераційному періоді з 30 пацієнтів, оперованих за різними способами, ускладнення виникли у 12, що становило 40\%. В основній групі з 30 пацієнтів, оперованих за представленою методикою, ускладнення у вигляді анастомозиту виникло лише у 1 пацієнта, що становило $(3 \pm 0,3) \%(\mathrm{p}<0,001)$.

Висновки. Отримані результати дають підставу запропонований спосіб органозберігаючої операції з метою збереження фізіологічної функції воротаря та нормального фізіологічного функціонування пілородуоденальної ділянки, який виключає ушивання перфоративної виразки без ліквідації стенозу воротаря та резекцію шлунка на фоні перитоніту, рекомендувати до застосування в клінічній практиці.

Ключові слова: виразкова хвороба; пілородуоденальна виразка; стеноз воротаря; перфоративна виразка; кровотеча; пенетрація; резекція шлунка; мобілізація дванадцятипалої кишки.
\end{abstract}

The most common complications of the peptic ulcer disease is pyloroduodenal stenosis, which should be considered as culmination of the disease chronic course. The pyloroduodenal stenosis occurrence is facilitated by frequent and prolonged periods of exacerbation of peptic ulcer disease, inadequacy of conservative treatment, the presence of penetrating ulcers, as well as perforated ulcers in the anamnesis, repaired by suturing. The duodenal ulcer in about $90 \%$ of the patients causes stenosis, much less often this complication is caused by the ulcer, which is localized in the pyloric canal. With pyloroduodenal stenosis, depending on the degree of its severity, pathological disorders of the main gastro-duodenal functions are prone to develop - secretory, motor-evacuatory, as well as of a pyloric function [1 - 3].

The reduction in the incidence of duodenal ulcers has been facilitated by the possibility for the general popula- 
tion to receive a modern comprehensive conservative treatment both on an outpatient basis and in a specialized hospital, but this approach, unfortunately, does not reduce the incidence of complications requiring surgery. According to various authors, the gastro-duodenal ulcer course is complicated in $8-15 \%$ of the patients [ $4-8]$.

Among the complications of the gastro-duodenal peptic ulcer, which are particularly threatening and insufficiently studied, there are the combined morbidities, the frequency of which ranges from 25 to 30\% [9 - 12]. Perforated gastroduodenal ulcers are more common in patients aged 20 -40 yrs old [12]. In recent years, postoperative mortality has dropped below 10\% [13]. Indications for the use of surgical methods in such patients are not yet clearly articulated [13]. The disadvantages of the perforation suturing are frequent recurrences of a peptic ulcer disease - from 27 to $45 \%$ [14]. Currently, the main method of treatment of perforated pyloroduodenal ulcers is recognized as emergency surgery. The advantages and disadvantages of palliative interventions, gastrectomy and various types of vagotomy with the gastric drainage operations are still discussed in the literature [17]. In recent years, in perforated ulcers of the pyloro-antral gastric region and duodenum different variants of vagotomy with the gastric drainage operations have become more widely used, but indications for both radical and palliative operations, and the choice of vagotomy with suturing are actively discussed in the literature $[18,19]$. The procedure suggested involves the functional maintaining of the portal and duodenum state, as well as eliminating of damage to the pylorus and duodenal sphincters, applying the organ-sparing surgery in contrast to other previously proposed methods.

The objective of the research: to develop a method of organ-preserving surgery, based on the ulcer suturing, to preserve the physiological function of the pylorus and the normal physiological functioning of the pyloroduodenal area in the patients with combined perforated, stenotic pyloroduodenal ulcers.

\section{Materials and methods}

The research have included 60 patients, operated on for complicated combined perforated and stenotic pyloroduodenal ulcers. The patients, depending on the diagnostic and surgical tactics applied, were divided into two groups. The control group consisted of 30 patients who underwent the standard suturing options. The main group consisted of 30 patients, in whom the developed method was applied. All 60 patients were operated mainly during the first two hours af-

Table 1. The nature and frequency of combined complications of duodenal ulcers

\begin{tabular}{|c|c|c|c|c|c|c|c|}
\hline \multirow{3}{*}{$\begin{array}{l}\text { The nature of the combined } \\
\text { complications of duodenal ulcers }\end{array}$} & \multicolumn{4}{|c|}{ Groups of patients } & & & \multirow{3}{*}{$\mathrm{p}<$} \\
\hline & \multicolumn{2}{|c|}{$\begin{array}{c}\text { control } \\
(\mathrm{n}=30)\end{array}$} & \multicolumn{2}{|c|}{$\begin{array}{l}\text { basic } \\
(\mathrm{n}=30)\end{array}$} & \multicolumn{2}{|c|}{ Together } & \\
\hline & $\mathrm{n}$ & $\%$ & $\mathrm{n}$ & $\%$ & $\mathrm{n}$ & $\%$ & \\
\hline Perforation + bleeding + stenosis & 7 & $23,3 \pm 0,8$ & 9 & $30 \pm 0,8$ & 16 & $26,7 \pm 1,0$ & 0,001 \\
\hline Perforation + stenosis & 5 & $16,6 \pm 0,7$ & 7 & $23,3 \pm 0,8$ & 12 & $20 \pm 0,5$ & 0,001 \\
\hline Penetration + perforation + stenosis & 18 & $60 \pm 0,9$ & 14 & $46,7 \pm 0,9$ & 32 & $53,3 \pm 0,6$ & 0,001 \\
\hline Total... & 30 & 100 & 30 & 100 & 60 & 100 & \\
\hline
\end{tabular}

Table 2. Types of surgical interventions for combined complications of duodenal ulcers

\begin{tabular}{|c|c|c|c|c|c|c|c|c|c|c|c|c|}
\hline \multirow{6}{*}{$\begin{array}{c}\text { The nature of } \\
\text { the combined } \\
\text { complications } \\
\text { of duodenal } \\
\text { ulcers }\end{array}$} & \multicolumn{10}{|c|}{ Groups of patients } & \multirow{2}{*}{\multicolumn{2}{|c|}{ Together }} \\
\hline & \multirow{2}{*}{\multicolumn{8}{|c|}{$\begin{array}{c}\text { control } \\
(\mathrm{n}=30)\end{array}$}} & \multirow{4}{*}{\multicolumn{2}{|c|}{$\begin{array}{c}\text { basic } \\
(\mathrm{n}=30) \\
\text { bougienage due to } \\
\text { ulceration } \\
\text { of the lumen of } \\
\text { the duodenum, } \\
\text { stomach and } \\
\text { suturing } \\
\text { (gastroduodeno- } \\
\text { anastomosis) }\end{array}$}} & & \\
\hline & & & & & & & & & & & \multirow{4}{*}{$\mathrm{n}$} & \multirow{4}{*}{$\%$} \\
\hline & \multirow{2}{*}{\multicolumn{2}{|c|}{ by Finney }} & \multicolumn{4}{|c|}{ pyloroplasty } & \multirow{2}{*}{\multicolumn{2}{|c|}{$\begin{array}{l}\text { suturing of an ulcer } \\
+ \text { gastroentero- } \\
\text { anastomosis }\end{array}$}} & & & & \\
\hline & & & \multicolumn{2}{|c|}{ by Jabouay } & \multicolumn{2}{|c|}{ by Jadd } & & & & & & \\
\hline & $\mathrm{n}$ & $\%$ & $\mathrm{n}$ & $\%$ & $\mathrm{n}$ & $\%$ & $\mathrm{n}$ & $\%$ & $\mathrm{n}$ & $\%$ & & \\
\hline $\begin{array}{l}\text { Perforation }+ \\
\text { bleeding }+ \\
\text { stenosis }\end{array}$ & - & - & - & - & 2 & $6,6 \pm 0,5$ & 7 & $23,4 \pm 0,8$ & 10 & $33,3 \pm 0,9$ & 19 & $31,6 \pm 0,9$ \\
\hline $\begin{array}{l}\text { Perforation }+ \\
\text { stenosis }\end{array}$ & 4 & $13,3 \pm 0,6$ & 3 & $10 \pm 0,6$ & 4 & $13,3 \pm 0,6$ & 4 & $13,3 \pm 0,6$ & 8 & $26,6 \pm 0,8$ & 23 & $38,4 \pm 0,6$ \\
\hline $\begin{array}{l}\text { Penetration }+ \\
\text { perforation }+ \\
\text { stenosis }\end{array}$ & - & - & - & - & - & - & 6 & $20 \pm 0,7$ & 12 & $40 \pm 0,9$ & 18 & $30 \pm 0,9$ \\
\hline Total... & 4 & $13,3 \pm 0,6$ & 3 & $10 \pm 0,6$ & 6 & $20 \pm 0,7$ & 17 & $56,6 \pm 0,6$ & 30 & 100 & 60 & 100 \\
\hline
\end{tabular}


ter hospitalization. In 16 patients a severe intoxication, unstable hemodynamics, manifestations of widespread peritonitis, infectious-toxic shock have required a short-term preoperative preparation. The target indicators of the preparation in these patients were considered to be the achievement of central venous pressure up to $8-12 \mathrm{~mm} \mathrm{Hg}$, average blood pressure - more than $65 \mathrm{~mm} \mathrm{Hg}$, indicators of saturation of hemoglobin in the venous blood - more than $70 \%$, diuresis - more than $0,5 \mathrm{ml} /(\mathrm{kg} \times \mathrm{h})$. All the patients were examined, according to the standard scheme: clinical examination, instrumental (radiological, ultrasound diagnosis of the abdominal cavity, electrocardiography), and the laboratory research (general analysis of blood and urine, biochemical analysis of blood: bilirubin, alanine aminotransferase, aspartate aminotransferase hepatitis).

\section{Results}

The nature and frequency of combined complications of duodenal ulcers in patients of the research groups are presented in Table 1.

The types of surgical interventions for combined complications of duodenal ulcers in patients of the researched groups are presented in Table 2.

Surgery was performed in all 60 patients in a volume of upper median laparotomy and gastric drainage surgery in various modifications with mandatory mobilization of the duodenum.

To solve the technically complex intraoperative situation and to prevent suturing of perforated ulcer without elimination of pyloric stenosis and avoiding gastric resection in conditions of peritonitis, a method of preserving of the pyloric functional state during suturing of perforated ulcer (Patent of Ukraine No. 141554 from 10.04.2020) is presented. [20].

Preservation of the functional state of the pylorus while the perforated ulcer suturing was realized as follows. When performing pyloroplasty in presence of perforated callous pyloroduodenal ulcer and stenosis of the pylorus (Pic. 1) with the ulcer size $2.5-3.0 \mathrm{~cm}$, the antrum and duodenum revision and mobilization with the help of the index finger, introduced through the perforation aperture, was done with subsequent finger bougienage of the stenosis with a minor damage to pathologically altered and healthy tissues of the pyloroduodenal area and at the site of a perforative opening of the ulcer (PiC. 2). In case of significant local tissue deficiency, severe infiltration and scarring of the tissues around the ulcer, the anterior and lateral duodenal walls were mobilized by inserting of the surgeon's index finger into its lumen with gradual freeing of duodenal wall and its ligament, connected with the retroperitoneal space. The peritoneal cover was cut on both sides to a length that depended on local conditions (Pic. 3) [21], to guarantee an adequate evacuation of gastric contents into the duodenum after suturing of their walls without a tension (PiC. 4).

Patient S., 42 years old (case history No. 1707), was hospitalized to the Surgical Department of the Chornobayiv Multidisciplinary Hospital with a diagnosis of perforated duodenal ulcer, subcompensated pyloroduodenal stenosis. After preoperative preparation, the patient was operated. During the operation, a callous ulcer with a diameter of $0.7 \mathrm{~cm}$ in the pyloroduodenal area and subcompensated pyloroduodenal stenosis were detected. The edges of the ulcer were dense with a pronounced inflammatory shaft. After treatment of the edges of the perforated ulcer in the pyloroduodenal zone and pylorostenosis there were difficulties in its suturing due to the lack of tissues of the anterior wall, scarring in the ulcer area. In this regard, the proposed method was used. Suturing of the pyloroduodenal area was performed with a two-row suture. The course of the postoperative period was without complications. The treatment in the immediate postoperative period was supplemented with antisecretory, antibacterial and eradication pharmacotherapy. Low-molecular-weight heparins were used for 7 to 9 days to prevent pulmonary embolism. In 10 days after
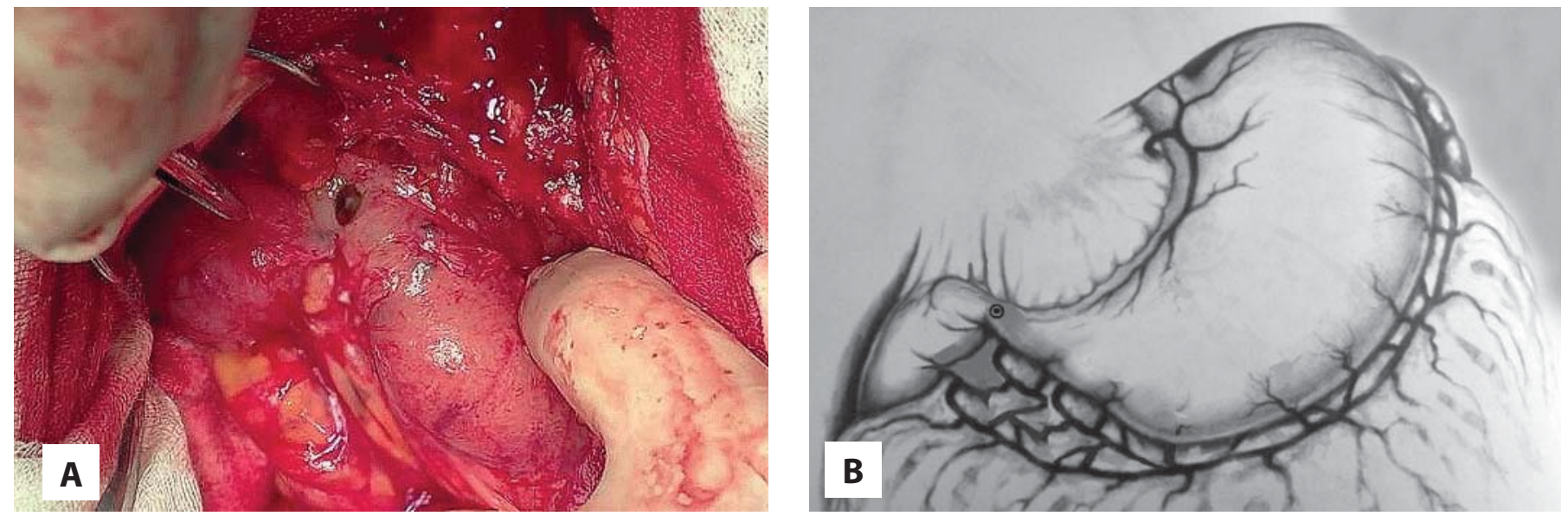

Picture 1.

Perforated callous pyloroduodenal ulcer with stenosis of the pylorus and a significant deficit of local tissues and severe infiltration and scarring of tissues around the ulcer: $A$ - intraoperative photograph, $B$ - scheme. 

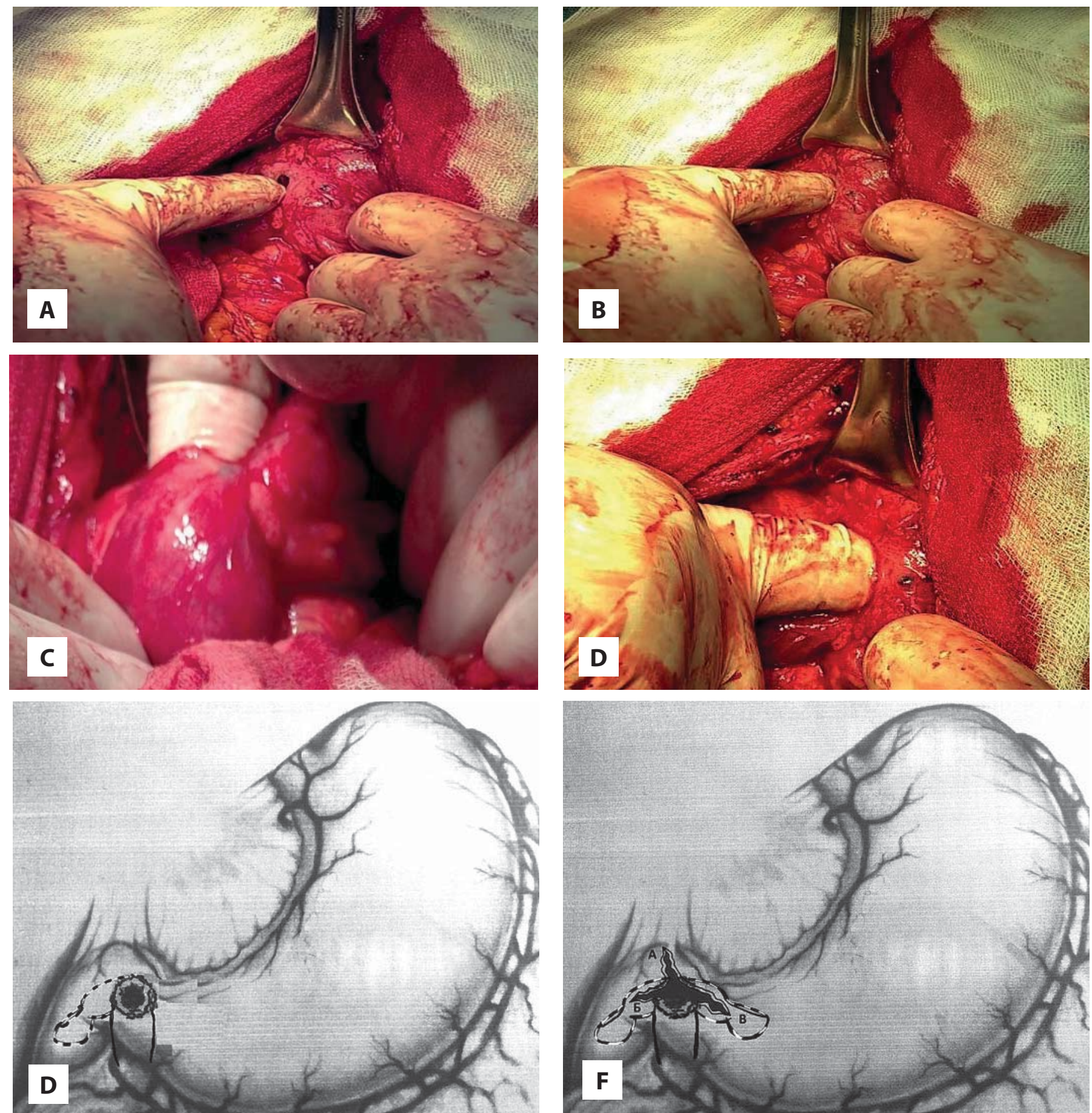

Picture 2.

Performing finger buzzing of the internal opening of the duodenum and stomach with minor damage when passing through $t$ he ulcer hole as pathologically altered and healthy tissues of the pyloroduodenal area: A, B, C,D - intraoperative photographs, $D, F$ - schemes.

the operation the patient was discharged from the hospital in a satisfactory condition.

The proposed method of pyloroplasty was used in $30 \mathrm{pa}-$ tients. No stenosis of the pylorus was noted, patency was preserved.

In the control group of 30 operated patients, complications have occurred in 12: pyloroduodenal stenosis (8), bleeding from the ulcer of the posterior wall of the duode- nal bulb (3), insufficiency of the gastro-enteroanastomosis sutures (1). The frequency of postoperative complications in the control group was $40 \%$.

In the main group of 30 operated patients, complications in the form of anastomositis have occurred in only 1 patient in whom penetration was combined with perforation and stenosis, constituting $(3 \pm 0.3) \%(p<0.001)$ of the complications. 


\section{Киінічна хірургія \\ Klinichna khirurhifa}

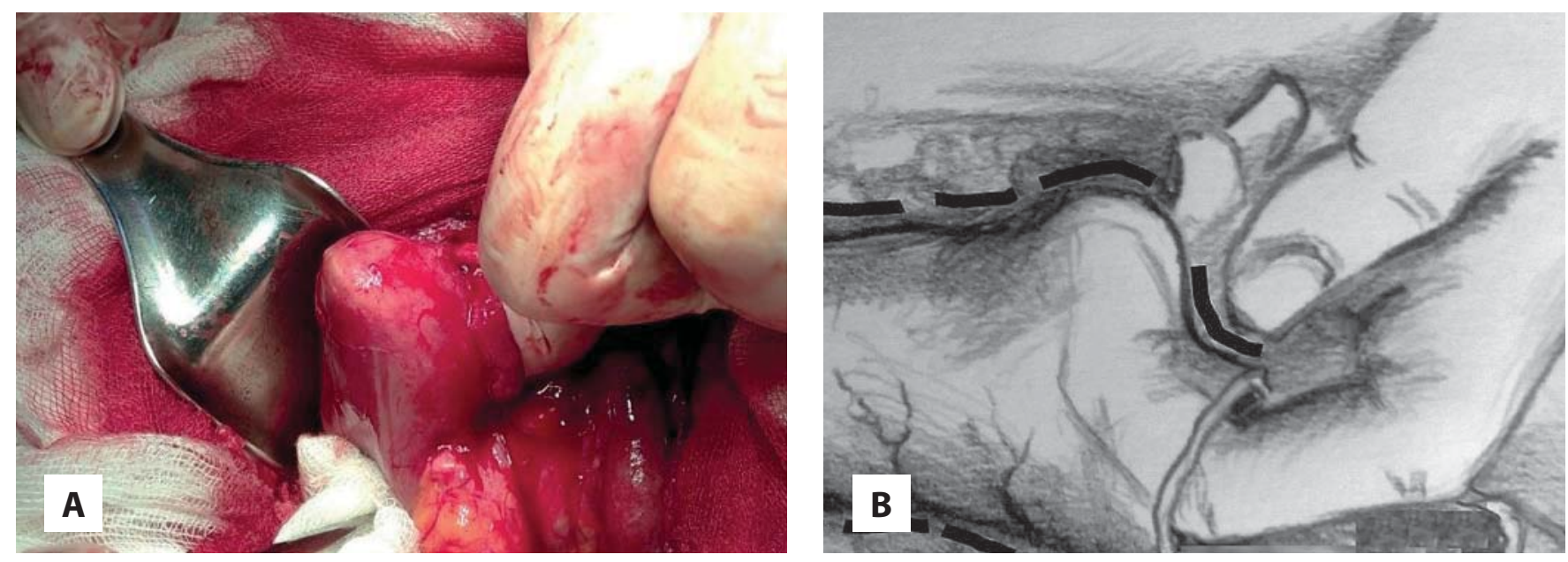

Picture 3.

Mobilization of joints in the pyloroduodenal area and duodenum: A - intraoperative photography, $B-$ scheme.
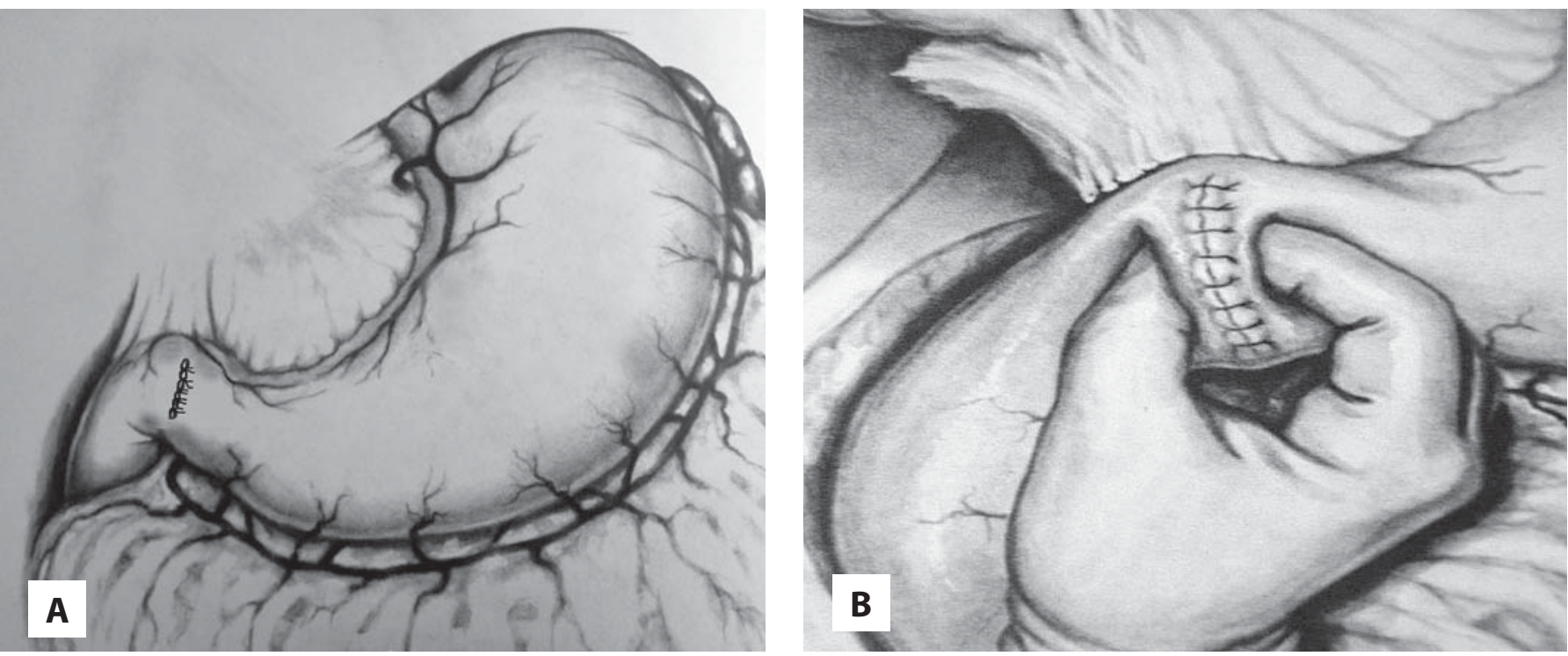

Picture 4.

Appearance after suturing of the walls of the duodenum and stomach without tension (A), patency is preserved (B).

\section{Discussion}

The method of intra-intestinal finger mobilization, proposed by the authors, in contrast to the method of mobilization by Vautrin - Kocher, allows without external instrumental traction to move the walls of the duodenum in all necessary directions, minimally injuring them. The developed method of the pyloric functional state preserving while doing suturing of the perforated pyloro-duodenal callous ulcer with stenosis has the following advantages over classical methods: Access to the narrowed openings of the duodenum and stomach is achieved through the perforated opening of the ulcer with subsequent treatment by the finger bougienage. Intraintestinal finger mobilization of the duodenum is performed according to the method of the authors [21]. Surgery does not disrupt the anatomical and topographic structures of the pyloroduodenal area and preserves the duodenal sphincters (portal sphincter, ampulo- duodenal sphincter, Kapanji sphincter, Oxner's sphincter). The method allows to inspect the duodenal posterior wall in the presence of an ulcer, improves technical conditions for the duodenal secure mobilization performance, prevents further complications (bleeding), provides reliability and tightness of the duodeno-gastric suturing without a tension.

\section{Conclusions}

The proposed method of the pyloroduodenal functional state preservation while doing the ulcer suturing procedure for combined complication of the pyloroduodenal ulcer by perforation and stenosis and in presence of reactive peritonitis, constituting of additional application of a surgeon finger through the perforative ulcer opening for secure intraluminal revision and mobilization of duodenum and bougienage of stenosis, avoids performance of pyloroplasty or gastric resection, minimizes the likelihood of the 
gastro-duodenal sutures failure, and may be recommended for use in clinical practice.

Finding. The research and writing of the article was financed by the authors at their own expense.

Contribution of each participant. Maksymchuk D. V. - author of the idea, writing the article; Mamchich V. I. - recruitment and analysis of material; Maksymchuk V. D. - statistical research and analysis of material, article design, bibliography.

Conflict of interest. The authors declare the absence of conflict of interest and their own financial interest in the preparation of this article.

Consent to publication. All authors have agreed to publish this manuscript.

\section{References}

1. Hattori A, Kawabata H, Umeda Y, Tsuboi J, Yamada R, Hamada Y, et al. Adult hypertrophic pyloric stenosis that improved by spontaneous double channel pylorus formation. JGH Open. 2020 Dec 2;5(2):317-9. doi: 10.1002/jgh3.12458. PMID: 33553675; PMCID: PMC7857292.

2. Kassegne I, Sewa EV, Kanassoua KK, Alassani F, Adabra K, Amavi K, et al. Management of peptic pyloroduodenal stenosis in Sylvanus Olympio teaching hospital in Lome (Togo). Med Sante Trop. 2016 May 1;26(2):189-91. English. doi: 10.1684/mst.2016.0549. PMID: 26987042.

3. Jaka H, Mchembe MD, Rambau PF, Chalya PL. Gastric outlet obstruction at Bugando Medical Centre in Northwestern Tanzania: a prospective review of 184 cases. BMC Surg. 2013 Sep 25;13:41. doi: 10.1186/1471-2482-13-41. PMID: 24067148; PMCID: PMC3849005.

4. Lai YK, Peng CY, Guo GH, Shu X. Use of over-the-scope clip for ulcer hemostasis after failure of both surgery and interventional therapy: A case report. Medicine (Baltimore). 2020 Oct 9;99(41):e22646. doi: 10.1097/MD.0000000000022646. PMID: 33031324; PMCID: PMC7544317.

5. Abbass A, Khalid S, Boppana V, Hanson J, Lin H, McCarthy D. Giant Gastric Ulcers: An Unusual Culprit. Dig Dis Sci. 2020 Oct;65(10):2811-7. doi: 10.1007/s10620-020-06573-z. PMID: 32875528; PMCID: PMC7462731.

6. Bupicha JA, Gebresellassie HW, Alemayehu A. Pattern and outcome of perforated peptic ulcer disease patient in four teaching hospitals in Addis Ababa, Ethiopia: a prospective cohort multicenter study. BMC Surg. 2020 Jun 15;20(1):135. doi: 10.1186/s12893-02000796-7. PMID: 32539756; PMCID: PMC7296920.

7. Jamal MH, Karam A, Alsharqawi N, Buhamra A, AlBader I, AlAbbad J, et al. Laparoscopy in Acute Care Surgery: Repair of Perforated Duodenal Ulcer. Med Princ Pract. 2019;28(5):442-8. doi: 10.1159/000500107. Epub 2019 Apr 16. PMID: 30995637; PMCID: PMC6771047.

8. Hsia NY, Tsai YY, Lin CL, Chiang CC. Increased risk of peptic ulcer in patients with early-onset cataracts: A nationwide populationbased study. PLoS One. 2018 Nov 9;13(11):e0207193. doi: 10.1371/ journal.pone.0207193. PMID: 30412615; PMCID: PMC6226190.

9. Kiringa SK, Quinlan J, Ocama P, Mutyaba I, Kagimu M. Prevalence, short term outcome and factors associated with survival in patients suffering from upper gastrointestinal bleeding in a resource limited-setting, the case of Mulago hospital in Kampala, Uganda. Afr
Health Sci. 2020 Mar;20(1):426-36. doi: 10.4314/ahs.v20i1.49. PMID: 33402931; PMCID: PMC7750076.

10. Byrne BE, Bassett M, Rogers CA, Anderson ID, Beckingham I, Blazeby JM, et al. Short-term outcomes after emergency surgery for complicated peptic ulcer disease from the UK National Emergency Laparotomy Audit: a cohort study. BMJ Open. 2018 Aug 20;8(8):e023721. doi: 10.1136/bmjopen-2018-023721. PMID: 30127054 ; PMCID: PMC6104767.

11. Daniel VT, Wiseman JT, Flahive J, Santry HP. Predictors of mortality in the elderly after open repair for perforated peptic ulcer disease. J Surg Res. 2017 Jul;215:108-13. doi: 10.1016/j.jss.2017.03.052. Epub 2017 Apr 6. PMID: 28688634; PMCID: PMC6889865.

12. Weledji EP. An Overview of Gastroduodenal Perforation. Front Surg. 2020 Nov 9;7:573901. doi: 10.3389/fsurg.2020.573901. PMID: 33240923; PMCID: PMC7680839.

13. Ahmadinejad M, Haji Maghsoudi L. Novel approach for peptic ulcer perforation surgery. Clin Case Rep. 2020 Jun 17;8(10):1937-9. doi: 10.1002/ccr3.3030. PMID: 33088523; PMCID: PMC7562834.

14. Jahagirdaar D, Bomanwar N, Joshi S. A Prospective Clinicoendoscopic Follow-up Study in Young Patients with Peptic Ulcer Perforation at a Tertiary Institute in Central India. Euroasian J Hepatogastroenterol. 2019 Jul-Dec;9(2):91-5. doi: 10.5005/jp-journals-10018-1306. PMID: 32117697; PMCID: PMC7047314.

15. Asanasak $P$. The case series of peritonitis due to perforated peptic ulcer: How does conservative management play role? Int J Surg Case Rep. 2019;58:74-6. doi: 10.1016/j.ijscr.2019.03.054. Epub 2019 Apr 5. PMID: 31009897; PMCID: PMC6479104.

16. Yamashita R, Takahashi N, Tsuboi K, Mitsumori N, Kashiwagi H, Yanaga K. Impact of truncal vagotomy on complicated peptic ulcer after distal gastrectomy with reconstruction by jejunal pouch interposition. Surg Case Rep. 2020 Jun 1;6(1):123. doi: 10.1186/ s40792-020-00879-w. PMID: 32488527; PMCID: PMC7266894.

17. Eğin S, Gökçek B, Yeşiltaş M, Hot S, Karakaş DÖ. Improvement of a duodenal leak: Two-way vacuum-assisted closure. Ulus Travma Acil Cerrahi Derg. 2019 Jan;25(1):89-92. doi: 10.5505/ tjtes.2018.22934. PMID: 30742295.

18. Lipof T, Shapiro D, Kozol RA. Surgical perspectives in peptic ulcer disease and gastritis. World J Gastroenterol. 2006 May 28;12(20):3248-52. doi: 10.3748/wjg.v12.i20.3248. PMID: 16718847; PMCID: PMC4087970.

19. Wu SC, Chen WT, Fang CW, Muo CH, Sung FC, Hsu CY. Association of vagus nerve severance and decreased risk of subsequent type 2 diabetes in peptic ulcer patients: An Asian population cohort study. Medicine (Baltimore). 2016 Dec;95(49):e5489. doi: 10.1097/ MD.0000000000005489. PMID: 27930533; PMCID: PMC5266005.

20. Maksimchuk DV, Maksimchuk VD, vynakhidnyky; Maksimchuk DV, Maksimchuk VD, patentovlasnyk. Method for preserving the functional state of the gatekeeper when suturing the perforated ulcer of the pyloric and the duodenum with stenosis of the exit from the stomach by Maksimchuk D.V., Maksimchuk V.D. Patent Ukraine No 141554. 2020 Apr 10. Ukrainian.

21. Maksimchuk DV, Maksimchuk VD, vynakhidnyky; Maksimchuk DV, Maksimchuk VD, patentovlasnyk. Sposib Maksimchuka Dmitra Volodimirovicha ta Maksimchuka Volodimira Dmitrovicha mobilizatsiyi dvanadtsyatipaloyi kishki pri hirurgichnomu likuvanni virazkovoyi hvorobi shlunka i dvanadtsyatipaloyi kishki. Patent Ukraine No 137083. 2019 Sept 25. Ukrainian.

Received: 29.11 .2020 